\title{
Las campañas electorales o la política
}

\section{como mercado}

El año 1998 constituye un año preelectoral. A medida que nos vayamos acercando a 1999 , los distintos partidos políticos irán afinando los componentes de la estrategia que deberán seguir para hacerse de la presidencia y vicepresidencia de la República. Cada partido político diseñará la campaña propagandística que crea le va a redituar los mejores resultados. No cabe duda de que en el interior de las estrategias político-partidarias las campañas propagandísticas ocupan un lugar de primera importancia. $Y$ es que los resultados electorales dependen, aunque no exclusivamente, del tipo de campaña diseñado; es decir, de la habilidad y sagacidad de los partidos para promoverse con un marketing que los haga atractivos para los electores.

Cualquiera diría que al comportarse de esa forma, los partidos políticos se comportan como vendedores y los votantes como compradores, y ciertamente ello es así, al menos en la concepción predominante de la política en nuestros días. En efecto, en la actualidad, distintos politólogos defienden la idea de que la política funciona según las reglas del mercado; esto es, que los partidos son instituciones que compiten entre sí por el voto de los electores, quienes "compran" con este voto el proyecto que les es ofrecido como mercancía durante cada período electoral. Los partidos hacen una oferta política y los votantes deciden si la compran o no; el partido que logra vender mejor su producto es el partido de mayor éxito, el partido que ve maximizados sus beneficios.

Por supuesto que para vender un producto hay que promocionarlo; y los partidos dedican buena parte de sus recursos para ello. Se trata de hacer que el proyecto político ofrecido (el producto) sea atractivo para los electores, para lo cual es importante la imagen del mismo. Una imagen que guste, que impacte los sentidos, que sea fácil de recordar e identificar por el segmento del mercado al que se quiere acceder. Pero también se trata de promocionar un producto apelando a su calidad, sobre todo en un mercado saturado de ofertantes. Y la calidad del producto ofrecido por los partidos (es decir, los proyectos políticos) se mide por el contenido de los mismos, la claridad para plantear los principales retos de la sociedad, la estrategia para enfrentarlos y los costos que ello va a suponer.

En otras palabras, la mercancía política para venderse requiere de una forma y un contenido. Dependiendo de cuán buenos sean ambos - de cuán superiores sean a los ofrecidos por los competidores - así será su posibilidad de ser adquirida por los compradores de proyectos políticos. De aquí que sea una preocupación de primera importancia dedicar esfuerzos (invertir) en mejorar tanto la calidad del producto como su imagen.

En buena medida, todos los partidos tienden a aceptar esta lógica mercantil; y si no, allí están los reveses electorales que los hacen caer en la cuenta de esta realidad tan poco digna de esa actividad que se consideró, entre los griegos, como una de las más nobles. Quien en la política contemporánea no asume con un mínimo de consecuencia las reglas del mercado está condenado al fracaso; quien piensa que basta con un proyecto sustantivo 
de gobierno y que la forma en que el mismo se presenta no cuenta, pues sencillamente está compitiendo mal. Al igual que lo hace quien pretende vender puras imágenes, por atractivas que sean, y se olvida de presentar proyectos con algún tipo de viabilidad económica, política y social.

En El Salvador, los partidos políticos lentamente han comenzado a asumir - y no sin resistencias- la competencia por el voto de los ciudadanos como una realidad de mercado. En la década de los setenta, la exclusión de competidores de izquierda y el fraude descarado impidieron que se pudiera desarrollar la lógica del mercado en la política. Durante los ochenta, pese a que esa lógica comenzó a ganar algún espacio, la guerra civil y la, en ese entonces vigente, exclusión de la izquierda no permitieron su avance más allá de lo que toleraban las exigencias de la guerra. Después de la firma de los acuerdos de paz, las cosas comenzaron a cambiar notablemente. Así, en 1994, hubo un ejercicio de competencia entre los principales proyectos ideológico-políticos (la izquierda, el centro y la derecha) y, de alguna manera, los competidores se asumieron como tales: como vendedores de proyectos político económicos.

Ciertamente, hubo partidos que no fueron totalmente coherentes con la opción mercado, aunque hubiesen accedido a jugar con ella. Y ello porque o manejaron una concepción reduccionista de lo que es pensar la política como mercado, o porque no contaban con la experiencia y habilidad para ello. El FMLN -y los demás partidos de izquierda que se vincularon a él en la coyuntura electoral de 1994 - compitió, pero no compitió; llevó ante los electores un proyecto poco claro, sin una agenda de problemas por enfrentar y, por ello, sin una propuesta de solución factible. Pero lo que es peor, lo que ofrecía el FMLN fue ofrecido mal, con poco atractivo, con una imagen pésimamente concebida.

ARENA, con más experiencia, con recursos casi ilimitados, asumió las elecciones, en 1994, como una competencia de mercado. Pero, en su perspectiva, de lo que se trataba era de promover única y exclusivamente la imagen del producto (su proyecto político económico), dejando totalmente de lado la promoción de su contenido y, en consecuencia, su calidad. De este modo, muchos de quienes compraron el producto ofrecido por ARENA lo hicieron motivados por el bonito envase de presentación del mismo, y no por lo que éste llevaba en su interior.
Del resto de partidos que participaron en las elecciones de $1994-$ el MAC (ya desaparecido), el MSN, el Partido de Conciliación Nacional y el Partido Demócrata Cristiano- cabe decir que no sólo fueron incapaces de hacerse de una imagen que fuese atractiva para un número suficiente de votantes, sino que además fueron incapaces de elaborar una propuesta que pudiera ser evaluada por éstos.

En la coyuntura electoral de 1997, el mercado político tuvo ofertas del FMLN, ARENA, PCN, PDC, MU, MSN, CD, el PD y el PRSC. Es decir, hubo productos de derecha, del centro y de izquierda; del centro derecha y centro izquierda. Cada uno quiso venderse mejor; esto es, cada uno pretendió ser comprado por un mayor número de votantes. Y, por supuesto, para alcanzar ese objetivo hicieron esfuerzos denodados por promoverse publicitariamente. En los resultados de ese evento electoral fue importante la imagen que cada uno logró forjarse, la cual ciertamente dejó a ARENA y al FMLN como los mejores oferentes políticos.

La "envoltura", como lo demostró ARENA en 1994, es clave para atraer compradores; incluso puede ser tan decisiva que haga obviar el contenido del "frasco". Pero también es un dato inobjetable que los "clientes" en la política (al igual que en otros ámbitos del mercado) se preocupan también por la calidad, y que ésta puede ser decisiva para que un producto pueda ser nuevamente adquirido o rechazado en una nueva oportunidad de compra. Eso también lo demostró, por la vía negativa, ARENA en 1997, pues su fiasco electoral puso de manifiesto que la calidad del ejercicio político está en la mira de los electores. Estos pueden ser "manipulados" infinidad de veces por la imagen (la forma), pero ello no será siempre así. También es importante la calidad (el contenido) de lo que se propone o hace. Cabría esperar que ambas cosas -imagen y calidad- fuesen componentes esenciales en las estrategias de los partidos políticos en la campaña electoral de 1998-1999.

Por lo demás, los procesos electorales -con todo lo que tienen de publicidad y promoción de imágenes- son parte esencial de la instauración de un ordenamiento democrático. Pero esa afirmación, dicha así sin más, puede dar lugar a graves equívocos porque puede entenderse que basta con que hayan eventos electorales relativamente transparentes y periódicos para tener garantizado el avance en la institucionalización democrática. Sin 
embargo, la periodicidad de las elecciones y su transparencia - suponiendo que ambas cosas están garantizadas - poco o nada dicen sobre la seriedad con que los contendientes políticos asumen su papel como representantes de los intereses ciudadanos, o sobre lo sustantivo de sus proyectos y propuestas electorales. Una visión meramente mercantil de la democracia respondería a esta objeción diciendo que si las debilidades apuntadas son importantes para los electores como compradores de proyectos políticos, el mercado se encargaría de orientar sus preferencias hacia ofertas más acordes con las mismas, haciendo que en la competencia política prevalezcan los partidos que sí satisfacen las expectativas ciudadanas.

En política, pues, el mercado - al igual que en la esfera económica - haría posible que la mejor oferta se impusiera en el gusto de los consumidores. Según los propugnadores de la extensión de la lógica del mercado a la política, esto sería lo más justo y equitativo, pues no respondería a más interés que al de los consumidores, a quienes no se puede privar del derecho a decir la última palabra en cuanto a sus preferencias.

A estas alturas de las discusiones en ciencias sociales, no puede negarse que en muchos aspectos la política - los partidos, los candidatos, la propaganda - se rige siguiendo una lógica de mercado; es decir, por muchos motivos, la política no es ajena a las leyes de la oferta y la demanda. Pero, al igual que en la economía, esas leyes no operan en estado puro, sino que son interferidas por una sinnúmero de factores que distorsionan la "asignación óptima de recursos" y que conllevan a que no siempre el consumidor se quede con -0 adquiera- el mejor producto. Y ello no como un caso aislado, lo cual en definitiva sería eliminado por la contundencia del mercado, sino como hecho generalizado en las relaciones entre compradores y vendedores. Porque, curiosamente, en las economías de mercado realmente existentes lo que predomina es la interferencia - estatal o privada - en la lógica del mercado, sea a nivel nacional o a escala internacional. Por consiguiente, no se puede apelar a ésta para legitimar la existencia de determinadas mercancías o esperar a que, por un automatismo del mercado, las mismas, si son deficientes o de baja calidad, van a desaparecer y ser reemplazadas por otras de mejor calidad. En muchas ocasiones, los consumidores adquieren determinados productos haciendo resistencia a interferencias

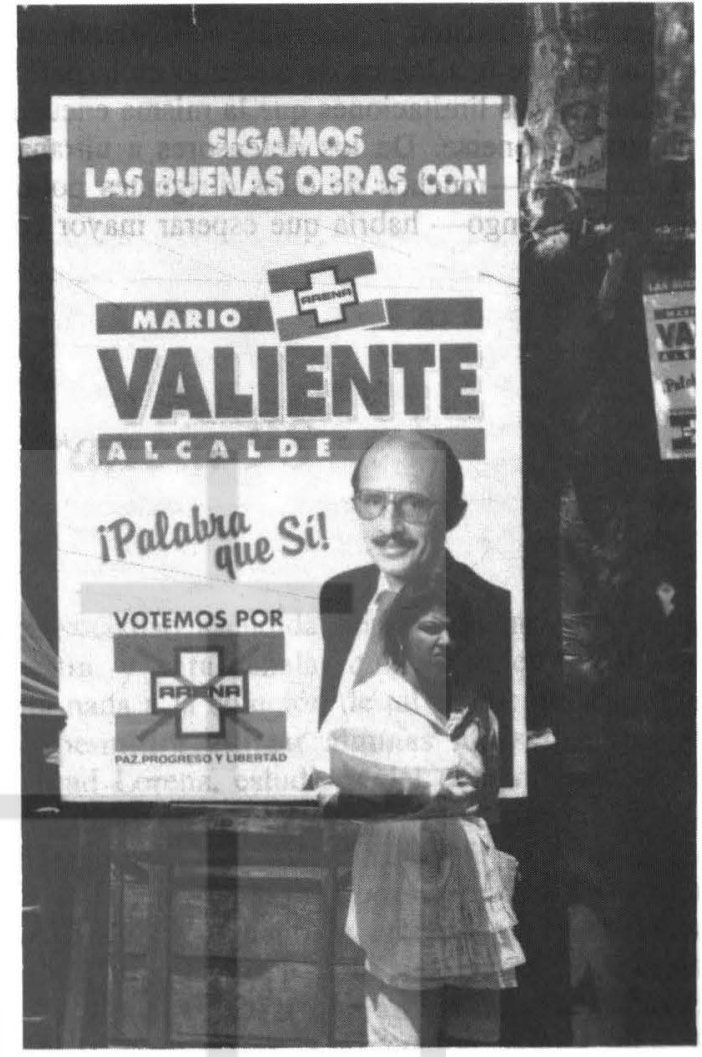

estatales o privadas que acompañan permanentemente el quehacer económico.

Pues bien, si en un terreno como el económico el mercado no tiene un dominio absoluto, mucho menos lo tiene en el ámbito político. Más aún, mucho menos lo puede tener en un país como el nuestro donde las manipulaciones más burdas son algo cotidiano. Confiar en que la lógica del mercado pondrá a los empresarios más aventajados e innovadores a la cabeza del quehacer económico es ignorar las redes de poder y el proteccionismo existente entre los grupos económicos y la élite que gestiona el aparato estatal. Confiar en que el mercado va a dejar fuera de la competencia y sin posibilidad de gobernar a aquellos partidos políti$\cos$ que no ofrezcan nada sustantivo es ignorar que las preferencias de los ciudadanos no sólo no apuntan a la mejor calidad de los productos políticos, sino que están mediatizadas por toda suerte de elementos, entre los cuales las falsas promesas, la frustración y la manipulación distorsionan la asignación óptima de recursos en política.

En nuestro país, en su gran mayoría, los parti- 
dos políticos existen y seguirán subsistiendo no porque impere una lógica de mercado en la política, sino por las limitaciones que la misma encuentra para imponerse. De los defensores a ultranza del mercado -muchos de ellos dirigentes políticos de alto rango- habría que esperar mayor co- herencia con lo que profesan, pues de lo contrario se exponen a ser devorados por el Dios al que rinden culto sin cumplir con los sacrificios que impone.

\section{Luis Armando González}

